\title{
PRODUCTION AND USE OF BIOENERGY IN POLAND IN THE CONTEXT OF THE DEVELOPMENT OF BIOECONOMY
}

Jarosław GOLĘBIEWSKI, Department of European Policy and Marketing, Faculty of Economic Sciences, Warsaw University of Life Sciences, ul. Nowoursynowska 166, 02-787 Warsaw, Poland, jaroslaw_golebiewski@sggw.pl (corresponding author)

Joanna RAKOWSKA, Department of European Policy and Marketing, Faculty of Economic Sciences, Warsaw University of Life Sciences, ul. Nowoursynowska 166, 02-787 Warsaw, Poland, joanna_rakowska@sggw.pl

Growing demand for energy, along with the depletion of traditional fossil fuels and the development of civilization, raises interest in the use of bioenergy in all sectors of the economy, including electricity, transport, heating, cooling, and industry. In developed countries bioenergy is an alternative to traditional non-renewable energy from fossil fuels, as its resources renew in natural processes, making it practically inexhaustible. Due to the reduction of greenhouse gas emissions, bioenergy is also more environmentally friendly than fossil energy. Thus bioenergy sector is a key segment of bio-economy and determines its competitiveness and development. Increase in bioenergy production, resulting from both market and energy policies, leads to greater interdependence between energy and agricultural markets, affects food and feed prices and change in land use.

The aim of this study was to identify changes in the bioenergy market in Poland in 2010-2015, present the role of bioenergy sector production in the structure of bio-economy, the changes in production and directions of biomass-based energy use and determine the importance of the major bioenergy markets in the structure of the energy market in Poland. The study was based on the aggregated statistical data on the acquisition and consumption of bioenergy in Poland, including energy from municipal waste, solid biofuels, biogas and liquid biofuels.

Findings prove that bioenergy is the most important renewable energy source in Poland. It is also a diversified source of energy, as it can be converted into solid, liquid and gaseous fuels. Although solid biofuels and liquid biofuels dominate in Poland, the share of biogas and energy produced from municipal waste is small. Concluding, bioenergy in Poland changes its character from traditional and local energy source into modern, international commodity.

Keywords: bioeconomy, bioenergy, Poland

\section{INTRODUCTION}

The term 'bio-economy' refers to a set of sectors within the national economy, which produce and process renewable resources. In the report titled 'The Knowledge Based Bio-Economy (KBBE) in Europe: Achievements and Challenges' the term 'bio-economy' was defined as follows: 'the bio-economy is the sustainable production and conversion of biomass, for a range of food, health, fibre and industrial products and energy. Renewable biomass encompasses any biological material to be used as raw material' (European Commission, 2010). In the sectoral approach, the bio-economy encompasses many areas of economic activity that are involved in the production and distribution of articles containing components of biological origin (European Commission, 2012; Adamowicz, 2014). The most important segments of bio-economy include primary production sectors such as agriculture, forestry and fishery, which produce biomass using natural resources (soil, air and water). The biomass can be next used as a primary raw material for other areas of bio-economy e.g. food production, chemical industry, pharmaceutical industry, production of cosmetics and textiles, as well as energy production (Chyłek, 2012).

In 2012, the European Commission adopted the 'Sustainable growth: a bio-economy for Europe' strategy, which seeks to create conditions for the development of an innovative, resource-efficient and competitive economy. In this economy it will be possible to reconcile food security with the use of renewable resources for industrial and environmental purposes (European Commission, 2012). The bio-economy development strategy also aims to increase the use of biomass raw materials, which will be used not only for traditional food applications, but more and more frequently also for modern, innovative, high value added products such as chemicals, pharmaceuticals, energy and fuels (Gołębiewski, Pająk, 2016).

Bioenergy sector, including the use of biomass for food, feed, materials and chemicals, is a key segment of bioeconomy (European Commission, 2012a) and determines its competitiveness and development (Schmid et al, 2012). Bioenergy is mainly obtained from organic matter, called biomass, i.e. all materials of biological origin not embedded in

Copyright (C) 2017 The Authors. Published by Aleksandras Stulginskis University. This is an open-access article distributed under the terms of the Creative Commons Attribution License (CC-BY 4.0), which permits unrestricted use, distribution, and reproduction in any medium, provided the original author and source are credited. 
geological formations (fossilised). Biomass can be used in its original form as fuel, or be converted into different kinds of solid, gaseous or liquid biofuels. These fuels can be used by the society and in all sectors of the economy, including production of electricity, transport, heating and cooling, as well as industrial processes (World Energy Council, 2016). Biomass is supplied by three sections - forestry, agriculture and waste. Although globally some of the waste is mixed with materials of fossil origin, like fossil-based plastics, most waste consists of a large share of biogenic material such as paper, wood, biogenic textiles, rubber, bio plastics, etc., and there are also large streams of waste and residues from agriculture, forestry, fishing, food chains, and all connected industries. In most countries, the first step in developing a modern bioenergy sector is to better utilise wastes and residues as sources of bioenergy (Gołębiewska, 2017).

Increasing interest in the use of bioenergy in all sectors of the economy results from growing demand for energy generated by the developing and developed societies and the depletion of traditional fossil fuels (World Energy Council, 2016). Although the increase in bioenergy production results from market conditions it needs to be supported by energy policies (Scarlat, 2015). The development of the EU energy policy started with the Green Paper 'A European Strategy for Sustainable, Competitive and Secure Energy' (European Commission, 2006) following the request of the European Council to develop a long-term and coherent energy policy. The European Council adopted energy and climate change objectives for 2020: to reduce GHG emissions, to increase the share of renewable energy, and to make an improvement in energy efficiency compared to the baseline projection. The Renewable Energy Directive 2009/28/EC (RED) on the promotion of renewable energy sources translated the energy targets for 2020 into legally-binding frameworks and tasks: the $20 \%$ share of renewable energy in final energy consumption and 10\% renewable energy use in the transport sector (EU, 2009). Next the Fuel Quality Directive 2009/30/EC (FQD) set a target of a 6\% GHG reduction for the fuels used in transport in 2020 (EU, 2009b). And so, bioenergy is expected to provide almost $60 \%$ of the renewable energy in 2020 (EU, 2009a).

Furthermore the communication 'A policy framework for climate and energy in the period from 2020 to 2030 ' put forward an integrated policy framework for the period beyond 2020 and up to 2030 to drive progress towards a lowcarbon economy (European Commission, 2014). It aims to build a competitive energy system that increases the security of energy supply, reduces energy dependence and creates new opportunities for growth and jobs. Targets proposed for 2030 include $40 \%$ reduction of GHG emissions compared to 1990 levels and at least $27 \%$ share of renewable energy in the final energy consumption.

The key constraint to the expansion of bioenergy production is the limited amount of land available to meet the needs for fuel, feed, and food in coming decades. Large-scale bioenergy production raises concerns about food versus fuel trade, demand for natural resources such as water, and its potential impacts on environmental quality. Policies to support bioenergy production have distributional implications for consumers and producers, farm and nonfarm sectors (Khanna et al., 2010). Moreover, the potential to gain significant independence from foreign oil for most countries, by relying simply on corn as feedstock for bioenergy is limited. This has increased interest in second-generation lignocellulosic feedstock that can increase the energy productivity of the land resource (Wicki, 2017).

The increasing production of biomass feedstock and conversion to energy has important direct and indirect economic consequences which influence the environmental and socio-economic performance of bioenergy systems and policies. In the past, agricultural markets and energy markets were not closely correlated. Higher energy prices and the use of conventional agricultural crops and wood pellets for bioenergy increased the correlation between energy markets and conventional markets for agricultural commodities and forestry production (Du, McPhail 2012; Baffes, Dennis 2013).

In Poland, the assumptions for the development of renewable energy have been laid down in the 'Strategy for the development of renewable energy' (Ministry of Environment, 2000), 'Program for power engineering' (Ministry of Economy, 2006) and 'Poland's energy policy until 2030' (Ministry of Economy, 2009). In 2010, the Council of Ministers accepted the 'National Action Plan on Renewable Energy' (Minister of Economy, 2010), which sets the increase in the use of renewable energy to $15.5 \%$ in 2020 as the strategic aim of the state policy in Poland. According to the documents promoting the use of energy from renewable sources, it is also essential to increase the diversification of energy supplies and to create conditions for the development of distributed energy based on local sources, which in 2007-2015 was also supported by EU funding under operational programmes 2007-2013 (Rakowska, 2016).

Taking into consideration the above, the aim of this study was to identify changes in the bioenergy market in Poland in 2011-2015, present the role of bioenergy sector production in the structure of bio-economy, evaluate changes in production and directions of biomass-based energy use and determine the importance of the major bioenergy markets in the structure of the energy market in Poland.

\section{RESEARCH METHODS}

The study was based on the aggregated statistical data on the acquisition and consumption of renewable energy, including bioenergy published in reports of the Central Statistical Office of Poland for 2011-2015. The statistics are expressed in units of energy, i.e. TJ - Terajuoules and Mtoe - million tonnes of equivalent oil. The data were also used for EU-28 according to the energy balance sheets drawn up and made available by the EUROSTAT.

The paper presents the stand point that the supply of bioenergy includes domestic production, plus imports, less exports and is corrected with inventory balances. The domestic use of bioenergy includes the end use of bioenergy, directly by the end users, the use of bioenergy as feedstock for production and the use of bioenergy by the energy sector itself.

The end (final) consumption consists of the use of bioenergy in production (industrial production), construction, transport, and by other users, including trade and services, households, agriculture and forestry. 


\section{RESEARCH RESULTS}

World bioenergy use in 2010 equalled 1277 Mtoe, which is about $10 \%$ of the total global primary energy use (IEA, 2012). About $60 \%$ concerned the traditional use of biomass for cooking and heating. Traditional use of bioenergy is the combustion of solid fuels such as firewood, charcoal and agricultural residues for cooking, heating and lighting. The remaining $40 \%$ was used in modern bioenergy systems. Modern bioenergy involves the use of biomass in producing higher value energy carriers, such as electricity, liquid and gaseous fuels, or heat and power in modern installations.

The industry and power sectors use more than half biomass in modern energy systems. Non- traditional biomass is expected to go up from 526 Mtoe in 2010 to nearly 1200 Mtoe by 2035, growing at a rate of 3.3\% per year (IEA, 2012). Both biofuels and power doubled their share in the world energy consumption and by 2035 are expected to reach 210 Mtoe and 420 Mtoe, respectively. Traditionally biomass for heat, power and industrial applications has been locally sourced, but trade becomes more and more important (IEA, 2012).

On April 23, 2009 the European Parliament and the European Council adopted Directive 2009/28/EC on the promotion of the use of energy from renewable sources, that set a number of tasks for the EU Member States, in particular: the common framework for the promotion of energy from renewable sources, mandatory national general targets defining total share of renewable energy in gross final energy use and the share of renewable energy in transport (EU, 2009). It assumed that the share of renewable energy in total primary energy will increase in all EU-28 countries (Figure 1).

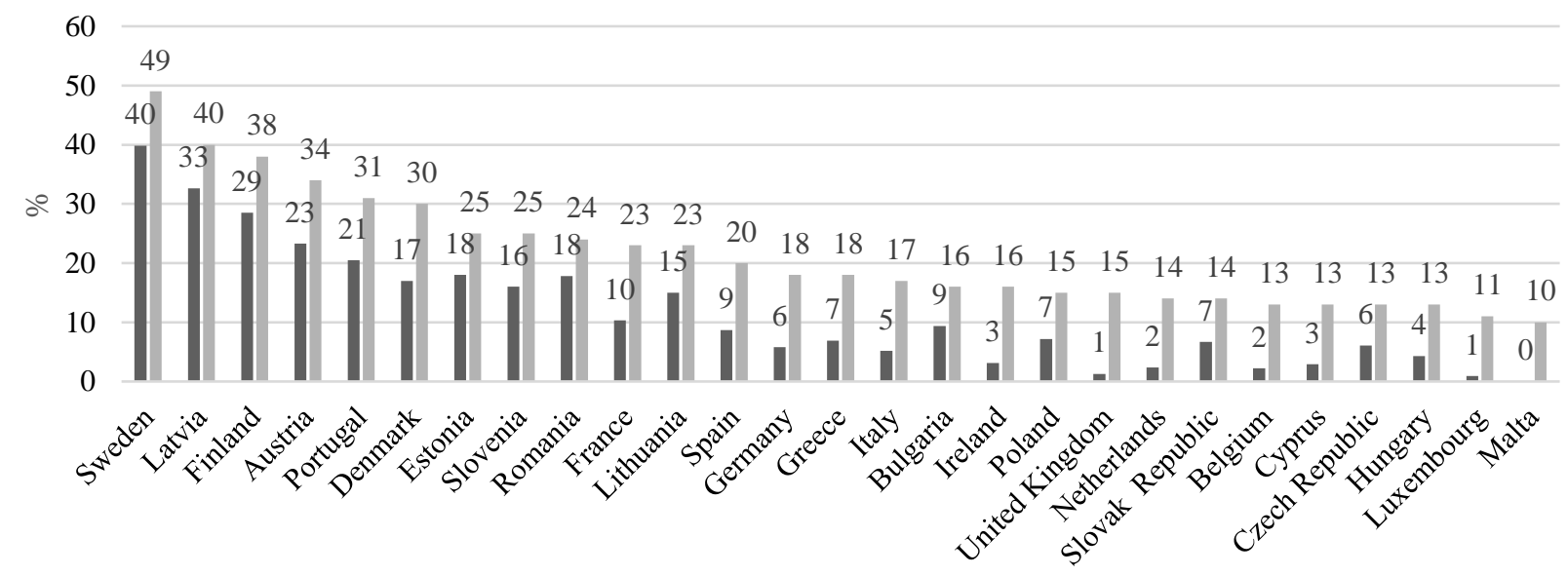

- Share of energy from renewable sources in gross final consumption of energy, 2005

Target for share of energy from renewable sources in gross final consumption of energy, 2020 (S2020)

Figure 1. National overall targets for the share of energy from renewable sources in gross final consumption of energy in 2020 Source: EU, 2009. Directive 2009/28/EC of the European Parliament and of the Council on the Promotion of the Use of Energy from Renewable Sources and Amending and Subsequently Repealing Directives 2001/77/EC and 2003/30/EC.

The highest level of these indices was established for Sweden and Latvia (over 40\%, and a little less for Finland, Portugal, Austria and Denmark - up to $30 \%$. These are country-specific targets and constitute reference points for their renewable energy development policies.

Table 1. Primary energy acquisition (including renewable energy sources) in selected EU countries

\begin{tabular}{|c|c|c|c|c|c|c|c|c|c|c|c|c|}
\hline \multirow{3}{*}{ Specification } & \multicolumn{8}{|c|}{ Primary energy acquisition } & \multirow{2}{*}{\multicolumn{4}{|c|}{$\begin{array}{c}\text { The share of energy from } \\
\text { renewable sources in the total } \\
\text { primary energy }(\%)\end{array}$}} \\
\hline & \multicolumn{4}{|c|}{ total (Mtoe) } & \multicolumn{4}{|c|}{$\begin{array}{c}\text { from the renewable energy } \\
\text { sources (Mtoe) }\end{array}$} & & & & \\
\hline & 2011 & 2012 & 2013 & 2014 & 2011 & 2012 & 2013 & 2014 & 2011 & 2012 & 2013 & 2014 \\
\hline UE-28 & 802.2 & 795.3 & 790.5 & 770.7 & 164.3 & 180.6 & 192.8 & 195.8 & 20.5 & 22.7 & 24.4 & 25.4 \\
\hline Austria & 11.4 & 12.4 & 12.1 & & 8.3 & 9.4 & 9.4 & 9.4 & 72.8 & 75.2 & 77.6 & 77.6 \\
\hline Czechs & 32 & 32 & 29.9 & 29.1 & 3 & 3.2 & 3.6 & 3.7 & 9.5 & 10.2 & 12.2 & 12.6 \\
\hline Finland & 17.1 & 17.1 & 18 & 18.1 & 9.2 & 10 & 9.9 & 10.1 & 53.8 & 58.2 & 55.2 & 55.8 \\
\hline France & 134.4 & 132.8 & 134.5 & 135.9 & 17.5 & 20.3 & 22.6 & 21 & 13 & 15.3 & 16.8 & 15.5 \\
\hline Netherlands & 64.4 & 64.7 & 69.3 & 58.4 & 3.2 & 3.9 & 4.4 & 4.6 & 5 & 6.1 & 6.3 & 7.8 \\
\hline Lithuania & 1.3 & 1.3 & 1.4 & 1.5 & 1.2 & 1.2 & 1.3 & 1.4 & 90.1 & 90.8 & 91.1 & 91.3 \\
\hline Germany & 122.7 & 122.7 & 120.6 & 119.9 & 29.5 & 32.1 & 33.7 & 36 & 24 & 26.1 & 27.9 & 30 \\
\hline Poland & 68.8 & 72.6 & 71.8 & 68.2 & 7.5 & 8.5 & 8.6 & 8.1 & 10.9 & 11.7 & 11.9 & 11.9 \\
\hline Slovakia & 6.2 & 6.2 & 6.4 & 6.3 & 1.4 & 1.4 & 1.5 & 1.4 & 22.5 & 23 & 22.9 & 22.8 \\
\hline Italy & 32 & 35 & 36.9 & 36.8 & 18.2 & 21.1 & 23.5 & 23.6 & 56.9 & 60.2 & 63.7 & 64.2 \\
\hline
\end{tabular}

Source: authors' elaboration based on GUS 2015.

In June 2016 the European Parliament adopted a resolution on reporting on the progress in renewable energy sector (European Parliament, 2016). The Parliament also called on the Commission to present a more ambitious climate and 
energy package to be carried out by 2030, setting a higher EU target for renewable energy of at least 30\%. The new EU target should be implemented by setting and achieving individual national targets. It was emphasized that the targets set for 2020 should be considered as the minimum during the revision of the Renewable Energy Directive. In its resolution of September 13, 2016 titled 'Towards a New Energy Market Structure' the European Parliament called for the development of a common definition of 'prosumers' at the EU level and for 'incorporating a new chapter on prosumers into the revised Renewable Energy Directive in order to eliminate major barriers and to stimulate investments in own production and own consumption of energy from renewable sources' (European Parliament, 2016a). To develop the EU renewable energy package, which was presented at the end of 2016, the European Commission carried out research and analysis on how to ensure sustainable supply, combined with the optimal use of biomass for energy after 2020 (PwC, 2017). Table 1 shows changes in the production of renewable energy in selected EU countries in 2011-2014, compared to the production of primary energy.

Production of renewable energy in UE-28 increased from 164 Mtoe in 2011 to more than 195 Mtoe in 2014. It occurred while the production of total primary energy decreased slightly from 802 Mtoe in 2011 to 770 Mtoe in 2014 . The share of the energy from renewable sources in the total primary energy increased in all the analysed countries (Table 1), although the dynamics of changes were different. The biggest share of energy from renewable sources in the total primary energy was observed in 2014 in Lithuania, Austria, Italy and Finland, which already at that time achieved the aims for 2020.

Table 2 shows the share of bioenergy in renewable energy in selected EU countries. The data prove that in 2011 2014 the share of bioenergy in the structure of renewable energy decreased from 67 down to 63\%, meaning that bioenergy made less than $2 / 3$ of the market of renewable bioenergy. Solid biofuels were the most important source of bioenergy. More than $43 \%$ of renewable energy was produced from wood biomass. Other sources of bioenergy, such as biogas and liquid biofuels account for about $7 \%$ of renewable energy production, while bioenergy from waste had the lowest share. The importance of bioenergy in renewable energy production varied considerably across the EU. The highest share of bioenergy in renewable energy production was achieved in 2014 by Lithuania and Poland, respectively 92.7 and $88.9 \%$.

Table 2. The structure of bioenergy acquisition in selected EU countries (the share of bioenergy in renewable energy acquisition in \%)

\begin{tabular}{|c|c|c|c|c|c|c|c|c|c|c|c|}
\hline Years & EU-28 & Austria & Czechs & Finland & France & Netherlands & Lithuania & Germany & Poland & $\begin{array}{c}\text { Slovaki } \\
\text { a }\end{array}$ & Italy \\
\hline \multicolumn{12}{|c|}{ Solid biofuels } \\
\hline 2011 & 49.3 & 52.8 & 68.6 & 83.4 & 49.4 & 35 & 84.6 & 36.1 & 85.2 & 56.5 & 26.2 \\
\hline 2012 & 48.2 & 48.3 & 66.3 & 79.7 & 46 & 31.6 & 82.8 & 34.1 & 82.4 & 55.9 & 34.4 \\
\hline 2013 & 45.9 & 49.9 & 63 & 81.4 & 46 & 27.5 & 80.8 & 32.4 & 80.2 & 52.4 & 31.7 \\
\hline 2014 & 43.8 & 46.7 & 62.9 & 80.1 & 43.3 & 28.3 & 82.2 & 31.7 & 76.6 & 52.7 & 27.7 \\
\hline \multicolumn{12}{|c|}{ Biogas } \\
\hline 2011 & 6.4 & 2 & 8.2 & 0.6 & 2 & 8.9 & 1 & 17.6 & 1.8 & 3.3 & 6.1 \\
\hline 2012 & 6.8 & 2.2 & 11.5 & 0.6 & 1.9 & 7.4 & 1 & 20 & 2 & 4.3 & 5.6 \\
\hline 2013 & 7.2 & 2.1 & 15.7 & 0.9 & 1.9 & 7 & 1.2 & 20.4 & 2.1 & 3.7 & 7.7 \\
\hline 2014 & 7.6 & 3.1 & 16.6 & 1 & 2.1 & 6.9 & 1.5 & 20.6 & 2.6 & 6.7 & 8.3 \\
\hline \multicolumn{12}{|c|}{ Liquid biofuels } \\
\hline 2011 & 6.4 & 3.2 & 7.3 & 2.4 & 11.7 & 13.6 & 7.1 & 10.9 & 5.8 & 12.2 & 3.4 \\
\hline 2012 & 6.3 & 2.8 & 6.7 & 2.8 & 11.7 & 26.6 & 9 & 9.3 & 8 & 10.5 & 1.8 \\
\hline 2013 & 6.6 & 2.4 & 6.3 & 3.7 & 10.7 & 33.9 & 9.2 & 9.4 & 8.2 & 10.1 & 2.3 \\
\hline 2014 & 7.1 & 4.1 & 7.1 & 4 & 12.2 & 33.4 & 8.2 & 10 & 9.2 & 10.2 & 2.6 \\
\hline \multicolumn{12}{|c|}{ Renewable municipal waste } \\
\hline 2011 & 5 & 1.7 & 2.6 & 1.5 & 6.5 & 27.3 & 0 & 8.2 & 0.4 & 1.3 & 4.6 \\
\hline 2012 & 4.7 & 1.5 & 2.6 & 1.9 & 6.2 & 21.8 & 0 & 8.1 & 0.4 & 1.3 & 3.8 \\
\hline 2013 & 4.5 & 1.6 & 2.3 & 2.2 & 5.2 & 18.3 & 0.9 & 8.7 & 0.4 & 1.1 & 3.5 \\
\hline 2014 & 4.6 & 1.9 & 2.3 & 2.4 & 5.6 & 17.4 & 0.8 & 8.4 & 0.5 & 0.8 & 3.6 \\
\hline \multicolumn{12}{|c|}{ Bioenergy total } \\
\hline 2011 & 67.1 & 59.7 & 86.7 & 87.9 & 69.6 & 84.8 & 92.7 & 72.8 & 93.2 & 73.3 & 40.3 \\
\hline 2012 & 66.0 & 54.8 & 87.1 & 85,0 & 65.8 & 87.4 & 92.8 & 71.5 & 92.8 & 72,0 & 45.6 \\
\hline 2013 & 64.2 & 56 & 87.3 & 88.2 & 63.8 & 86.7 & 92.1 & 70.9 & 90.9 & 67.3 & 45.2 \\
\hline 2014 & 63.1 & 55.8 & 88.9 & 87.5 & 63.2 & 86 & 92.7 & 70.7 & 88.9 & 70.4 & 42.2 \\
\hline
\end{tabular}

Source: authors' elaboration based on CSO 2015 and EUROSTAT.

Between 2011 and 2014 the share of biofuels in renewable energy decreased from $49.3 \%$ to $43.8 \%$ and municipal waste from $5 \%$ to $4.6 \%$. On the other hand, growth was noted in case of biogas and liquid biofuels. As regards biogas, its use increased in the Czech Republic, Germany and Italy. National balances of renewable energy sources in Poland for 2011-2015 were elaborated based on the results of statistical surveys on the amount of energy produced and consumed in the given year. Figure 2 shows data on total primary energy generation in 2011-2015 in Poland, including energy from renewable sources. 


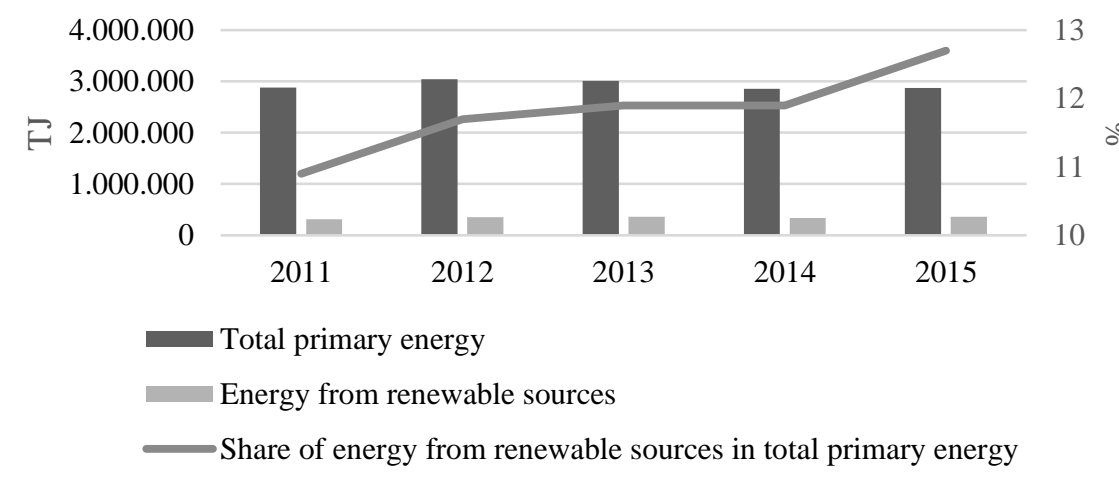

Figure 2. The acquisition of total primary energy, including renewable sources energy in TJ in Poland in 2011-2015 Source: authors' elaboration based on CSO 2015.

As shown in Figure 2, a relatively stable level of total primary energy production was accompanied by a systematic increase in the acquisition of energy from renewable sources (in 2015 by $16.0 \%$ higher than in 2011). The share of renewable energy in total primary energy increased from $10.9 \%$ in 2011 to $12.7 \%$ in 2015.

Table 3 presents detailed data on the balance of bioenergy in Poland in 2011-2015. According to the presented information, in 2015 the total consumption of bioenergy in Poland exceeded 326.8 TJ. Nearly $64 \%$ of the available bioenergy resources were used in by final consumers, including both industrial production and other segments of the economy such as transport, construction and households, trade and services, agriculture and forestry. Approximately $40 \%$ of bioenergy was used in the energy sector as a feedstock for production.

Table 3. Balance of bioenergy total in Poland in 2011-2015 (acquisition and use in TJ)

\begin{tabular}{|c|c|c|c|c|c|c|c|c|c|c|}
\hline Specification & 2011 & 2012 & 2013 & 2014 & 2015 & 2011 & 2012 & 2013 & 2014 & 2015 \\
\hline Acquisition $^{1}$ & 290987 & 329325 & 324542 & 300151 & 312860 & na & na & na & na & na \\
\hline Imports $(+)$ & 22598 & 8267 & 6988 & 39625 & 36430 & na & na & na & na & na \\
\hline Exports (-) & 1438 & 1919 & 6029 & 17730 & 22087 & na & na & na & na & na \\
\hline Change of stock $(+/-)$ & -91 & -248 & 670 & -65 & -412 & na & na & na & na & na \\
\hline \multirow{2}{*}{ Total domestic use } & 312056 & 335425 & 326171 & 321981 & 326791 & na & na & na & na & na \\
\hline & \multicolumn{5}{|c|}{ in TJ } & \multicolumn{5}{|c|}{ in \% of domestic use } \\
\hline Used as feedstock for production ${ }^{2}$ & 109926 & 142548 & 122465 & 131006 & 127932 & 35.2 & 45.7 & 39.2 & 42.0 & 41.0 \\
\hline Use by the energy sector itself ${ }^{3}$ & 162 & 160 & 122 & 39 & 0 & 0.1 & 0.1 & 0.0 & 0.0 & 0.0 \\
\hline \multirow[t]{2}{*}{ End use (final) ${ }^{4}$} & 201968 & 192717 & 203585 & 190937 & 198860 & 64.7 & 61.8 & 65.2 & 61.2 & 63.7 \\
\hline & \multicolumn{5}{|c|}{ in TJ } & \multicolumn{5}{|c|}{ in $\%$ of final use } \\
\hline Production & 41819 & 43708 & 54776 & 56446 & 59033 & 20.7 & 21.6 & 27.1 & 27.9 & 29.2 \\
\hline Construction & 125 & 120 & 115 & 81 & 6 & 0.1 & 0.1 & 0.1 & 0.0 & 0.0 \\
\hline Transports & 11090 & 1727 & 1061 & 648 & 5979 & 5.5 & 0.9 & 0.5 & 0.3 & 3.0 \\
\hline Other users & 148934 & 147163 & 147633 & 133762 & 133842 & 73.7 & 72.9 & 73.1 & 66.2 & 66.3 \\
\hline \multicolumn{11}{|l|}{ of which: } \\
\hline trade and services & 9780 & 9113 & 9559 & 8674 & 8891 & 4.8 & 4.5 & 4.7 & 4.3 & 4.4 \\
\hline households & 115000 & 116850 & 116850 & 105450 & 105450 & 56.9 & 57.9 & 57.9 & 52.2 & 52.2 \\
\hline agriculture and forestry & 24154 & 21200 & 21223 & 19638 & 19501 & 12.0 & 10.5 & 10.5 & 9.7 & 9.7 \\
\hline
\end{tabular}

${ }^{1}$ Acquisition means the amount of energy obtained from natural resources (only primary energy carriers). ${ }^{2}$ Use as feedstock for production means the use of energy carriers which are the technological raw material for energy conversion into other energy carriers. ${ }^{3}$ Energy consumption by the energy sector - energy consumption by auxiliary equipment used in the conversion process, such as: fuel feeders, pump and fan drives, etc. ${ }^{4}$ End (final) use means the use of energy carriers by the users (industry, services, households) for their technological, production and living needs.

Source: authors' elaboration based on CSO 2015.

\section{CONCLUSIONS AND DISCUSSION}

Bioeconomy, which is perceived as a remedy limiting dependence on fossil fuels, is an important element of the economic development concept at the beginning of the 21 st century. It addresses problems of the contemporary social and economic development in three dimensions: the local connected - among others - with rural development or employment growth, the national relating to food security and energy security and the global focusing on the reduction of greenhouse gas emissions. Bio-economy can contribute to the development of agricultural holdings and the economic growth of rural areas, provided that the regulatory systems for the production and processing of agricultural and forestry raw materials ensure the balance between economic and environmental objectives.

Renewable sources of energy play an important role in the global, European and Polish economy. The increase in bioenergy production is driven by declining manufacturing costs resulting from the use of modern technologies, rising fossil fuel prices and by policies supporting markets of renewable energy in the world and in EU as well.

The presented findings prove that bioenergy is the most important renewable energy source in Poland as in 2014 it amounted to nearly $89 \%$ of renewable energy production, which ranked Poland the second after Lithuania in this respect. 


\section{Proceedings of the $8^{\text {th }}$ International Scientific Conference Rural Development 2017}

Biomass is also a source of diversified energy, as unlike other sources, it can be converted into solid, liquid and gaseous fuels. Solid biofuels and liquid biofuels dominate in Poland, while the share of biogas and energy produced from municipal waste is small. Concluding, bioenergy in Poland changes its character from traditional and local energy source into modern, international commodity.

\section{REFERENCES}

1. Adamowicz, M., 2014. European Concept of Bioeconomy and its bearing on Practical Use. Economic and Regional Studies, Vol. 7, No. 4.

2. Rakowska, J., 2016. Commune self-governments as beneficiaries of EU cohesion policy in 2007-2013 (2015). WULS-SGGW Publishing House, Warszawa. [in Polish]

3. Baffes, J., Dennis, A., 2013. Long-term Drivers of Food Prices. Policy Research Working Paper 6455, the World Bank, Washington, DC, USA.

4. Chyłek, E.K., 2012. Bioeconomy in agricultural and food sector. Food Industry, Vol. 66, pp. 32-35. [in Polish]

5. CSO, 2015. Energy from Renewable Sources in 2015. Statistical Information and Analysis, Central Statistical Office of Poland, Warszawa.

6. Du, X., McPhail, L., 2012. Inside the Black Box: The Price Linkage and Transmission between Energy and Agricultural Markets, The Energy Journal, Vol. 33, pp. 171-194. https://doi.org/10.5547/01956574.33.2.8

7. EU, 2009. Directive 2009/28/EC of the European Parliament and of the Council on the Promotion of the Use of Energy from Renewable Sources and Amending and Subsequently Repealing Directives 2001/77/EC and 2003/30/EC.

8. EU, 2009a. Directive 2009/30/EC of the European Parliament and of the Council of 23 April 2009 Amending Directive 98/70/EC as Regards he Specification of Petrol, Diesel and Gas-Oil and Introducing a Mechanism to Monitor and Reduce Greenhouse Gas Emissions and Amending Council Directive 1999/32/EC as Regards the Specification of Fuel used by Inland Waterway Vessels and Repealing Directive 93/12/EEC.

9. European Commission, 2006. Green Paper. A European Strategy for Sustainable, Competitive and Secure Energy. COM(2006) 105 Final.

10. European Commission, 2010. The Knowledge - Based Bioeconomy (KBBE) in Europe. Achievements and Challenges. Full conference report. http://cleverconsult.eu/clever3/wp-content/uploads/2015/02/KBBE_2020_BE_presidency.pdf

11. European Commission, 2012. Commission Staff working Document accompanying Communication on Innovating for Sustainable Growth: A Bioeconomy for Europe, SWD (2012), 11 final, Brussels 13.02.2012.

12. European Commission, 2012a. Communication from the Commission to the European Parliament, the Council the European Economic and Social Committee and the Committee of the Regions. Innovating for Sustainable Growth: A. Bioeconomy for Europe. COM (2012), 60 final, Brussels 13.02.2012.

13. European Commission, 2014. A Policy Framework for Climate and Energy in the Period from 2020 to 2030, COM(2014) 15.

14. European Parliament, 2016. European Parliament resolution of 23 June 2016 on the renewable energy progress report (2016/2041(INI)), P8_TA(2016)0292.

15. European Parliament, 2016a. European Parliament resolution of 13 September 2016 on Towards a New Energy Market Design (2015/2322(INI)), P8_TA(2016)0333.

16. Eurostat, http://ec.europa.eu/eurostat/statistics-explained/index.php/Consumption_of_energy, accessed on November 2, 2017.

17. Gołębiewska, B., 2017. Changes in waste management in the EU countries, Integrated and sustainable regional development: marketing and sustainable consumption. Proceedings of the International Scientific Conference Economic Science for Rural Development, no 45, Jelgava. p. 87-94.

18. Gołębiewski, J., Pająk, K., 2016. A sustainable bioeconomy in Europe - the European Union's policy and strategy. [in] Political rents of European farmers in the sustainable development paradigm: international, national and regional perspective, Czyżewski B., (ed.), Polish Scientific Publishers PWN, Warsaw, pp. 69-81.

19. IEA, 2012. World Energy Outlook 2012, International Energy Agency, Paris.

20. Khanna, M., Scheffran, J., Zilbrman, D., 2010. Bioenergy Economics and Policy: Introduction and Overview. (in) Handbook of Bioenergy Economics and Policy, Springer, New York, pp. 439. https://doi.org/10.1007/978-1-4419-0369-3

21. Minister of Economy, 2010. National Renewable Energy Action Plan. Available at http://www.ebbeu.org/legis/ActionPlanDirective2009_28/national_renewable_energy_action_plan_poland_pl.pdf (Accessed on 15.11.2011).

22. Ministry of Economy, 2006. Program for Power Engineering, retrieved from http://www.ekoefekt.pl/dokumenty/dokument_13.pdf

23. Ministry of Economy, 2009. Poland's Energy Policy till 2030. Available at http://www.nettg.pl/uploads/docs/201112/1323348675-politykaenergetycznaost.pdf (Accessed on 15.11.2010).

24. Ministry of Environment, 2000. Development Strategy for Renewable Energy. Available at http://www.pga.org.pl/prawo/strategiaOZE.pdf (Accessed on 15.11.2011).

25. PwC, 2017. Sustainable and optimal use of biomass for energy in the EU beyond 2020. VITO, Utrecht University, TU Wien, INFRO, Rütter Soceco.

26. Scarlat, N., Dallemand, J.N., Monforti-Ferrario, F., Nita, V., 2015. The role of biomass and bioenergy in a future bioeconomy: Policies and facts Environmental Development, pp. 3-34.

27. Schmid, O., Padel, S., Levidow, L., 2012. The Bio-Economy Concept and Knowledge Base in a Public Goods and Farmer Perspective. Bio-based and Applied Economics, Vol. 1(1). pp. 47-63. 
28. Wicki, L., 2017. Food and bioenergy - evidence from Poland, Rural development and entrepreneurship: bioeconomy production and co-operation in agriculture. Proceedings of the International Scientific Conference, pp. 299-305, $27-28$ April 2017, Jelgava.

29. World Energy Council, 2016. World Energy Resources. Bioenergy 2016. Available at https://www.worldenergy.org/wpcontent/uploads/2017/03/WEResources_Bioenergy_2016.pdf (Accessed on 15.11.2016). 